\title{
UJI AKTIVITAS ANTIBAKTERI DARI ISOLAT DAUN TENDANI (Goniothalamus Macrophyllus Hook. f. \& Thomson.)
}

\author{
Viriyanata Wijaya $^{1, *}$, Supriyatna ${ }^{2}$, Tiana Milanda ${ }^{2}$ \\ ${ }^{1}$ Fakultas Farmasi Universitas Mulawarman \\ ${ }^{2}$ Fakultas Farmasi Universitas Padjadjaran \\ *email: viriya_wijaya@yahoo.com
}

\begin{abstract}
ABSTRAK
Tumbuhan tendani (Goniothalamus macrophyllus) secara empiris digunakan sebagai obat luar untuk infeksi kulit pada suku Dayak Punan. Penelitian ini bertujuan untuk mengetahui aktivitas senyawa aktif antibakteri yang terkandung dalam isolat dari fraksi etil asetat Daun G. macrophyllus. Fraksi etil asetat adalah fraksi teraktif yang diperoleh dari hasil pengujian aktivitas antibakteri. Isolat diperoleh dari proses pemisahan dan pemurnian menggunakan kromatografi kolom dan kromatografi lapis tipis preparatif. Isolat diuji dengan menggunakan metode difusi agar. Hasil uji aktivitas antibakteri isolat dengan konsentrasi $1,2 \mathrm{mg} / 50 \mu \mathrm{L}(2,4 \%)$ terhadap $S$. aureus ATCC 25923 menghasilkan diameter zona hambat sebesar $7,85 \mathrm{~mm}$.
\end{abstract}

Kata kunci : Goniothalamus macrophyllus, aktivitas antibakteri, Staphylococcus aureus, isolat, senyawa aktif

\section{PENDAHULUAN}

Berbagai penelitian beberapa tumbuhan dari genus Goniothalamus memiliki beragam aktivitas antimikroba. Ekstrak bunga dan batang G. grandflorous memiliki aktivitas antijamur terhadap Trichophyton mentagrophyte dan Trichophyton verrucosum (Khan, et al., 1999).

Wiart (2007) menggunakan ekstrak metanol, fraksi n-heksan, dan fraksi diklorometan 22 spesies dari 160 spesies dari genus Goniothalamus $(13,7 \%)$ untuk diujikan ke berbagai bakteri Gram positif dan Gram negatif. Dari ke-22 spesies tersebut, daun $G$. scortechinii menghasilkan aktivitas antibakteri terhadap Gram positif dan Gram negatif.

Ekstrak akar G. scortechinii memiliki aktivitas antibakteri terhadap Bacillus sp., Staphylococcus aureus
ATCC 25923, S. aureus ATCC 29213, Enterococcus faecalis ATCC 24922, Pseudomonas aeruginosa ATCC 27853, Escherichia coli ATCC 25922, Klebsiella pneumoniae, Shigella sonnei dan Shigella flexneri (Wiart, 2007).

Stirillakton yang diisolasi dari salah satu tumbuhan dari genus Goniothalamus, yaitu goniotalamin oksida, menunjukkan aktivitas antimikroba dan embriotoksik (Buckingham, 1994). Minyak atsiri dari ranting dan akar G. macrophyllus memiliki aktivitas antibakteri terhadap $S$. aureus resisten vankomisin dan Staphylococcus epidermidis serta memiliki aktivitas antijamur terhadap Candida albicans (Siti Humeirah, et al., 2010).

Sampai saat ini belum ada informasi ilmiah tentang aktivitas antibakteri dari isolat daun $G$. macrophyllus terhadap $S$. aureus, 
sehingga penelitian tentang aktivitas antibakteri perlu untuk dilakukan.

\section{ALAT DAN BAHAN}

Alat-alat yang digunakan dalam penelitian ini adalah hot plate (Toyomi, HP 115F1), inkubator (Sakura, IF-4), jangka sorong (Vernier Calipers), jarum ose, laminar air flow (Minihelic), mikropipet 10-100 $\mu \mathrm{l}$ (Biohit Proline), tip mikropipet ukuran 10-100 $\mu \mathrm{L}$ (Eppendorff), microplate (Biohit Proline), otoklaf (Hirayama, IA-1000), oven (Memmert 200 dan Memmert 400-800), pembakar spiritus, timbangan analitik (Mettler Toledo, AL204) dan alat-alat gelas yang umum dipakai di Laboratorium Mikrobiologi Farmasi, Fakultas Farmasi, Universitas Padjadjaran.

Bahan tumbuhan yang digunakan dalam penelitian ini adalah daun tendani yang berasal dari kawasan hutan Sungai Baru di Kecamatan Babulu Darat, Kabupaten Penajam Pasir Utara, Kalimantan Timur.

Bahan kimia yang digunakan adalah etanol 70\% (PT. Dover Chem), aseton (PT. Dover Chem), DMSO/dimetilsulfooksida (Merck), suspensi Mc. Farland 0,5 (9,5 mL asam sulfat $1 \% \mathrm{~b} / \mathrm{v}$ dan $0,5 \mathrm{~mL}$ barium klorida $1 \% \mathrm{v} / \mathrm{v})$ dan air suling.

Biakan bakteri yang digunakan adalah S. aureus ATCC 25923 yang berasal dari PT. Biofarma, Bandung. Medium pertumbuhan atau medium uji yang digunakan adalah NA/Nutrient Agar (Oxoid, Basingstoke, UK) dan NB/Nutrient Broth (Oxoid, Basingstoke, $\mathrm{UK})$.

\section{METODE}

Pengujian aktivitas antibakteri fraksi terhadap S. aureus ATCC 25923 dilakukan dengan metode difusi agar dengan tahapan kerja meliputi :

1. Pembuatan Medium
Medium Nutrien Agar (NA) dibuat dengan cara melarutkan $28 \mathrm{~g}$ NA ke dalam $1 \mathrm{~L}$ air, suling kemudian dipanaskan hingga larut. Sebanyak $5 \mathrm{~mL}$ NA cair dituang ke dalam tabung reaksi, lalu dan dimiringkan $45^{\circ}$ sehingga membentuk agar miring. Medium Nutrient Broth (NB) dibuat dengan cara melarutkan $8 \mathrm{~g}$ NB ke dalam $1 \mathrm{~L}$ air suling, kemudian dipanaskan hingga larut.

2. Sterilisasi Alat dan Medium

Alat dan medium yang akan digunakan disterilisasi dalam otoklaf selama 15 menit pada suhu $121^{\circ} \mathrm{C}$.

3. Penyiapan Suspensi Bakteri Uji

Bakteri uji S. aureus ATCC 25923 ditanamkan di atas permukaan NA miring, lau diinkubasikan selama 18-24 jam pada suhu $37^{\circ} \mathrm{C}$. Sebanyak 1 ose bakteri uji dimasukkan $5 \mathrm{~mL}$ medium NB dalam tabung reaksi, lalu diinkubasikan selama 18-24 jam pada suhu $37^{\circ} \mathrm{C}$. Kekeruhan supensi disesuaikan dengan suspensi standar Mc. Farland 0,5, sehingga suspensi bakteri tersebut mengandung $10^{8} \mathrm{CFU} / \mathrm{mL}$.

4. Uji Aktivitas Antibakteri Isolat

Sebanyak $10 \mu \mathrm{L}$ suspensi bakteri uji dimasukkan ke dalam cawan petri steril, lalu ditambahkan $10 \mathrm{~mL}$ NA yang masih cair. Cawan digoyang-goyangkan supaya bakteri dan NA tercampur secara homogen, lalu dibiarkan hingga memadat. Setelah memadat, dibuat lubang-lubang pada agar menggunakan perforator berdiameter $7 \mathrm{~mm}$. Sebanyak $20 \mu \mathrm{L}$ dari masing-masing variasi konsentrasi fraksi, dimasukkan ke dalam lubang-lubang tersebut menggunakan mikropipet 10-100 $\mu \mathrm{L}$.

Sebanyak $1,2 \quad \mathrm{mg}$ isolat dilarutkan dalam $50 \mu \mathrm{L}$ aseton, sehingga diperoleh konsentrasi 2,4 \%. Masingmasing sebanyak $20 \mu \mathrm{L}$ isolat dan aseton (kontrol pelarut) dimasukkan ke lubang pencadang. Cawan petri diinkubasi selama 24 jam pada suhu $37^{\circ} \mathrm{C}$ di inkubator. Diameter zona hambat yang 
terbentuk diukur menggunakan jangka sorong.

\section{PEMBAHASAN}

Isolat SF IV $\mathrm{B}_{1.3}$ (isolat dari fraksi etil asetat) dilarutkan dengan aseton, karena sifat pelarutnya mudah menguap dan untuk melarutkan silika gel. Hasil uji aktivitas antibakteri isolat dengan konsentrasi 1,2 mg/50 $\mu \mathrm{L}(2,4 \%)$ terhadap S. aureus ATCC 25923 menghasilkan diameter zona hambat sebesar 7,85 mm.

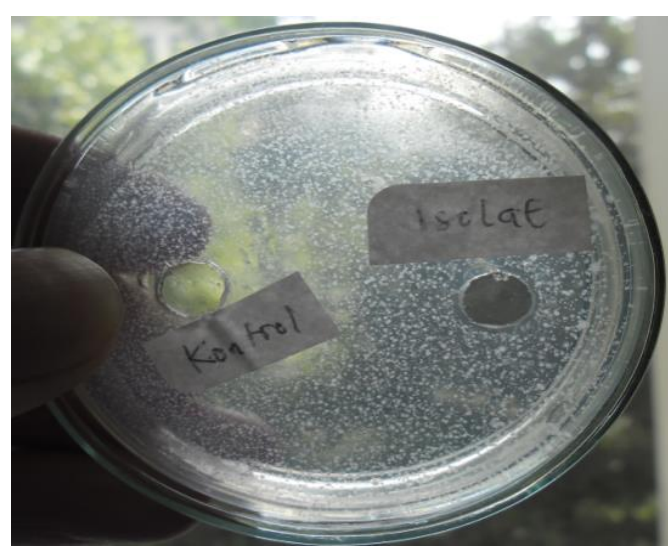

Gambar 1. Hasil uji aktivitas antibakteri isolat SF IV B 1.3

\section{KESIMPULAN}

Berdasarkan penelitian yang telah dilakukan, diperoleh kesimpulan bahwa isolat berpotensi mempunyai aktivitas antibakteri terhadap $S$. aureus ATCC 25923.

\section{UCAPAN TERIMA KASIH}

Penulis mengucapkan terima kasih atas bantuan biaya penelitian melalui Beasiswa Pascasarjana (Beasiswa Unggulan 2012) a.n. Viriyanata Wijaya dari Ditjen DIKTI (Direktorat Jenderal Pendidikan Tinggi) Kementrian Pendidikan dan Kebudayaan RI.

\section{DAFTAR PUSTAKA}

1. Buckingham, J. 1994. Dictionary of natural products vol. 3 (G-L). London:
Chapman \& Hall, hal 2609, ISBN 0412466201

2. Khan, M. R.; Komine, K.; Omoloso, A. D. 1999. Antimicrobial Activity of Goniothalamus grandiflorus, Pharmaceutical Biology, 37, hal 340342

3. Siti Humeirah, A.G; M. A. Nor Azah, M. Mastura, J. Mailina, J. A. Saiful, H. Muhajir dan A. M. Puad, 2010. Chemical constituents and antimicrobial activity of Goniothalamus macrophyllus (Annonaceae) from Pasoh Forest Reserve, Malaysia. African Journal of Biotechnology Vol. 9(34), hal 55115515, ISSN, hal 1684-5315

4. Wiart, C. 2007. Goniothalamus species: A source of drugs for the treatment of cancer and bacterial infection? Evid. Based Comp. Alternat. Med., 4(3): hal 299-311 